\title{
China Analysis - Les Nouvelles de Chine
}

Guangdong's Policies in the Face of Economic Crisis and Jobs for Young Graduates: Crisis Within a Crisis

Pierre Nordmann and Camille Bondois

\section{(2) OpenEdition \\ Journals}

Electronic version

URL: http://journals.openedition.org/chinaperspectives/4781

DOI: 10.4000/chinaperspectives.4781

ISSN: 1996-4617

Publisher

Centre d'étude français sur la Chine contemporaine

\section{Printed version}

Date of publication: 1 April 2009

Number of pages: $94-97$

ISSN: 2070-3449

\section{Electronic reference}

Pierre Nordmann and Camille Bondois, «China Analysis - Les Nouvelles de Chine », China Perspectives [Online], 2009/1 | 2009, Online since 01 April 2011, connection on 15 September 2020. URL : http:// journals.openedition.org/chinaperspectives/4781 
This section, prepared by the Asia Centre (www.centreasia.org), draws mainly on the press in Chinese, aiming to reflect the point of view of the People's Republic of China on international questions and issues related to Greater China.

\section{Guangdong's Policies in the Face of Economic Crisis}

\section{Analysis by Pierre Nordmann based on:}

- Zhou Qiong and Fu Yanyan, "Difficulties of 'double transfer' in Guangdong," Caijing, 8 December 2008.

- Zhou Qiong, "Reforming the Pearl River Delta," Caijing, 24 November 2008.

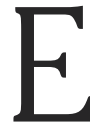
conomic crisis hit Guangdong, the southern province bordering Hong Kong and Macao, just as its growth rate was slowing after many years of acceleration. Current economic policies seek to reverse that trend more than to tackle the crisis.

The Pearl River Delta (PRD) in Guangdong Province pioneered China's economic reforms in the 1980s and remains a symbol of their success. The region's exports account for nearly 30 percent of China's total exports.

The region owes its success in part to its proximity to Hong Kong: drawn by the low cost of labour and the Chinese government's fiscal incentives, businesses from the former British colony moved their low-value-added, labour intensive industries to the region, setting up tens of thousands of small and medium enterprises (SMEs).

Thirty years later, this growth model has reached its limits: increasing land and labour costs have reduced the region's competitiveness, and the delta's energy- and resource-hungry industries are exacerbating environmental degradation.

Aware of these limits, the provincial authorities wish to usher the delta towards advanced and high technology activities. The authorities are taking a dual approach: moving low-value-added units to the province's less developed areas, and integrating more closely with Hong Kong and Macao. Since November 2008, however, the economic crisis has hit Guangdong's economic model hard, and the authorities have had to revise their agenda. The new priority is to safeguard jobs and the province's SMEs. After months of hesitation, the provincial authorities made an official declaration of support to SMEs on 1 December 2008.
Only a few months earlier, in May, they had announced the adoption of a new policy incompatible with propping up SMEs. The so-called "double transfer" policy had sought to change the province's economic development model. It was based on the simple fact that the PRD, which accounts for 30 percent of Guangdong's area and 50 percent of its population, has had extremely rapid economic growth for 30 years, while the northern, western, and eastern areas of the province are lagging behind: according to a Guangdong Academy of Social Sciences researcher interviewed by $\mathrm{Cai}^{-}$ jing magazine, per capita GDP in the PRD is four times that of the province's outlying areas. Moreover, the concentration of industries in the delta has added to pressure on resources and the environment: water pollution ${ }^{(1)}$ and energy bottlenecks ${ }^{(2)}$ are among numerous problems.

The solution the authorities envisaged was to relocate labour-intensive, low-value-added industries to less developed regions and to attract advanced industries and highvalue services to the delta. This policy included provisions for labour retraining. People in less developed regions of Guangdong were to be trained to meet the needs of newly relocated secondary and tertiary enterprises. At the same time, the better qualified workers from these regions were to be encouraged to move to the PRD.

Some 50 billion yuan (5.24 billion euros) was allocated for the 2008-2012 period for infrastructure construction in the

\footnotetext{
1. World Bank Helps Clean up China's Pearl River," China.org.cn, 22 March 2007.

2. Zheng Caixiong, "Guangdong Gears Up for Power Shortage," China Daily, 29 February
} 2008 
less developed areas, relocation of industries, and retraining, and 2.5 billion yuan (26 millions euros) as incentives for enterprises. Furthermore, the success of the industry relocation policy was to be added to the criteria for evaluating local cadres.

However, since the "double transfer" policy was announced in May 2008, the PRD's economic scenario has changed greatly. Falling external demand, the yuan's appreciation, rising labour costs following a new labour contract law, and the tightening of credit have squeezed firms in the region.

According to Caijing, Guangdong's industrial, political, and academic circles questioned the rationale of the double transfer policy in the prevailing economic situation: many people felt the priority should be the survival rather than the transfer of enterprises. This was echoed by officials in Dongguan, one of the PRD's nine prefectures: while a few continued to back the province's announced policy, most wanted enterprises to be modernised right where they were. Many officials also doubted the PRD's ability to attract high technology firms, advanced industry, and high-value services, citing the region's lack of qualified personnel.

Central authorities were also sceptical of the double transfer policy. On 12 November 2008, Wang Yang, who has been provincial Communist Party secretary since December 2007 and a Politburo member since October 2007, announced during a visit to Zhangijiang, in the west of Guangdong, that local authorities would no longer try to prop up firms in difficulty. In fact, Wang said, "Failed enterprises belong to a backward production method," and "their elimination is part of market mechanism." Two days later, however, Premier Wen Jiabao, while visiting Guangdong, publicly called for strong measures to support SMEs facing difficulty. A week later, Wang reiterated his position. ${ }^{(3)}$ Finally, on 1 December 2008, the province announced steps to support SMEs, mothballing the double transfer policy.

Wang has also been behind the initiative for integrating the PRD, covering nine prefectures in Guangdong as well as Hong Kong and Macao. ${ }^{(4)} \mathrm{A}$ little while after he took up his party post in Guangdong, Wang launched a consultation with several authorities and research institutes in the province. According to Caijing, Wang twice consulted Hong Kong chief executive Donald Tsang during the report preparation process. In March 2008, during the annual session of the National People's Congress, Wang hawked its conclusions to different ministries. The unpublished report recommended facilitating trade and investment exchanges among Hong Kong, Macao, and the Chinese mainland through simplification of customs and of procedures linked to the free trade and investment accord under the CEPA (Closer Economic Partnership Arrangement) signed in 2003 by the mainland, Hong Kong, and Macao.

The report included an ambitious roadmap for integrating the three sides' financial sectors: it envisaged the creation of a pilot zone for financial cooperation between Hong Kong and Shenzhen "before 2010." This pilot was to subsequently include Macao and eight other mainland prefectures by 2015: the financial institutions of Hong Kong, Macao, and the PRD prefectures were to receive the same treatment in each others' territories, and foreign exchange control for investments was to be suspended. Finally, with a 20-year horizon, the report also proposed that central authorities delegate part of their legislative responsibility in order to enable the pilot zone to acquire necessary competences for harmonising the three sides' financial sectors.

According to Caijing, the report drew the central authorities' attention to the issue of integrating the PRD, and a series of measures were announced for strengthening cooperation among the delta's three partners. Thus, an amendment to CEPA was signed on 29 July 2008 by Hong Kong and the mainland, granting Hong Kong firms greater access to the mainland, especially to Guangdong, from 2009. A week later, the governments of Guangdong, Hong Kong, and Macao announced the financing of a major infrastructure project - the construction of a bridge linking Hong Kong, Macao, and the mainland starting from 2010.

As economic conditions worsened by the end of 2008, the government took note of the difficulties facing export SMEs in the delta. On 18 December, it announced a plan to support the PRD's development, underlining the importance of cooperation among its different zones. Finally, a step towards the yuan's convertibility was taken on 24 December: it would be used for settling commercial payments among the Yangtze Delta, the PRD, and Hong Kong and Macao. This measure will primarily benefit export industries in the PRD region.

Meanwhile, academics interviewed by Caijing were not optimistic about prospects for the measures, saying the authorities are still far from adopting institutional changes needed for ensuring the PRD's integration. •

3. Wu Zhong, "Regions Won’t Dance to Beijing Tune," Asia Times Online, 26 November 2008.

4. Denise Tsang, "Recalibrating World's Production Line," South China Morning Post, 8 December 2008. 


\section{Jobs for Young Graduates: Crisis Within a Crisis}

Analysis by Camille Bondois based on:

- "6.1 million students apply for public service posts," Zhongguo Xinwen Zhoukan (China Newsweek), 8 January 2009.

- "Zheng Gongcheng: The state must establish a more just/equitable/fair framework for job creation," Zhongguo Xinwen Zhoukan (China Newsweek), 8 January 2009.

W hile at first it seemed that China was relatively sheltered from the global financial crisis, to the point of being seen as a possible saviour, it rapidly began to show multiple signs of weakness: 20 million migrant workers lost their jobs, ${ }^{(5)}$ and thousands of firms closed down. Disquiet in the country's interior is growing. The unemployment rate in December 2008 was 4.2 percent, the highest in five years. Among young graduates it was 12 percent. ${ }^{(6)}$

Employment for graduates is one of the more nerve-wracking issues in the crisis, and Chinese authorities have accorded it priority: in June 2009, as many as 6.1 million young graduates will enter the job market, joining one million graduates from 2008 who are still looking for work.

China Newsweek looks at the employment problem for young graduates, the consequences of joblessness, and the factors behind the phenomenon, profiling a Beijing law student, Chen Zao, and interviewing Zheng Gongcheng, an NPC standing committee member and professor at People's University, who is also an expert on social issues.

The weekly does focus on the effects of the 2008 financial crash, but only to the extent that it has exacerbated a much older and deeper problem linked to the evolution of an unbalanced economic model highly lacking in social protection. How does the joblessness problem among young graduates highlight the larger economic malaise? What are its effects and challenges, and how is the state responding?

Chen Zao's situation illustrates the battle upcoming graduates face in their job search. This school year is characterised by an unprecedented uncertainty gripping campuses. Unlike in previous years, by late December a majority of students from universities in coastal cities had failed to sign a job contract. Reduction in the numbers employed at major firms, a freeze or suppression of posts, and the collapse of thousands of firms in Guangdong, Fujian, and the Yangtze
Delta ${ }^{(7)}$ led to a steep drop in job opportunities for young graduates. SMEs, the main employers of young graduates in China,${ }^{(8)}$ were hit hard by the crisis, further hurting students' job prospects. The key sectors of finance and foreign trade turned moribund, disappointing students who had been eyeing them. The phenomenon of students applying for jobs far removed from their educational background gained prominence. As a direct consequence, civil service examinations are now attracting substantial numbers of worried students. This is not only because the government decided to raise its recruitment quota, but mainly because, in the context of economic crisis, such jobs, considered less attractive and not as well paid as the private sector, are seen as offering greater job security, guaranteed social protection, and less harsh competition.

These issues go beyond the frame of the current crisis; they have more complex origins, not "foreign" this time, but intimately linked to the evolution in the growth model China adopted years ago.

In education, alongside the exponential rise in the number of students entering university faculties, ${ }^{(9)}$ the government's attitude swung from strong interventionism - to the extent that it took charge of assigning graduates to different sectors - to complete disengagement, obliging students to compete in the open market. China Newsweek blames an ill-adapted higher education system in which a third of the students fail to get jobs in the sectors they trained for. According to

5. "20 million jobless migrant workers return home," Xinhuanet, 2 February 2009.

6. "China's Solution for Unemployed College Grads: State Jobs in the Boonies," Washington Post, 30 January 2009.

7. Figures from the SME office in Guangdong show that between January and September 2008 , some 60,000 firms closed down.

8. China Newsweek notes that more than 50 percent of students are recruited by SMEs.

9. The number of students has risen from 200,000 in the 1980 s to 6 million in 2008 due to the policy of expanding higher education. 
Zheng Gongcheng, it is also a non-egalitarian, discriminatory system in which an impressive CV and personal connections play a disproportionately large part, leading to wasted potential.

More seriously, the difficulties facing young job-seekers are linked to weaknesses in post-reform China's socio-economic system. China Newsweek notes that the number of graduates has been rising faster than the number of available jobs suited to their qualifications. The job-creating power of economic growth has mostly shrunk: too much industrial concentration; major state firms' monopoly over key sectors, limiting the expansion prospects of private enterprises while public sector jobs have been declining; a "down market" industrial sector and difficulty creating jobs for qualified people; a major regional imbalance in the country's development - all of these factors impose pressure on the job market. Moreover, the priority given to exports has for too long been at the expense of the internal market. To conclude, in the 1980s a one-point rise in the GDP led to two million jobs, as against a mere 800,000 in 2008. Added to this, the social protection system remains incomplete and unequal, leading to a climate of insecurity. Looking beyond the crisis, the government ought to give priority to these weaknesses: if not, the job difficulties facing graduates will only grow, blocking the transformation of the students' potential into a real source of competitiveness.

The government announced a series of urgent short-term measures in response to public unease over the crisis. Notably, it once again raised recruitment quotas in public service and state firms. But, says China Newsweek, the quotas have already been filled in many departments, and in state firms weakened by the crisis, ${ }^{(10)}$ the additional burden to the salaried ranks would be difficult to bear, all of which limits the effectiveness of such measures. Moreover, the state is encouraging students to perform community service in rural and backward areas that severely lack qualified personnel. ${ }^{\text {(II) }}$ However, this is not something students like Chen Zao aspire to.

In the long term, Zheng says, the state ought to set right the five major weaknesses of the system. ${ }^{(12)}$ These include the territorial balance and the need to invest in major infrastructure works to reduce geographic inequalities and to extend employment zones. More crucially, the state needs to adopt an adequate universal social protection system covering retirement, health, unemployment, and disability. This implies greater state engagement to avoid adding to the costs of firms and individuals. ${ }^{(1)}$ This reform is crucial not only for increasing worker confidence through a more fair, stable, and competitive job market, but also for boosting internal consumption that can generate further job creation.

It would thus seem that the international financial crisis and its immediate effects on jobs in China affords an opportunity to take a fresh look at an economic model found wanting, and already rocked by scandal and social unrest in recent years. It is also an opportunity to speed up social reforms that have been sorely held back since the launch of economic reforms and the cracking of the "iron rice bowl." The issue is not merely to survive the crisis and stem social unrest in 2009, but above all to clean up the system and usher in sustainable development. ${ }^{\bullet}$

\section{Translated by N. Jayaram}

10. State enterprise profits fell for the first time in six years by 26 percent in 2008 , according to Li Rongrong, chairman of the State-owned Assets Supervision and Administration Commission of the State Council (SASAC).

11. See also "China's Solution for Unemployed College Grads: State Jobs in the Boonies," Washington Post, 30 January 2009.

12. The five major weaknesses are, according to Zheng Gongcheng, inadequate social protection; an unequal job market and one based on guanxi (connections); an economic structure that fails to create enough jobs for qualified people; geographic imbalance in development; and a limited vision of students' capacity.

13. "Social" costs (health, retirement, joblessness, housing) account for 50 percent of the average household's budget, according to China Newsweek 